\title{
Application of heat pipe and nano fluid in the structure of drill for drilling process: Experimental and mathematical evaluation
}

\author{
Farshad Farahbod ${ }^{1}$ \\ ${ }^{1}$ Department of Chemical Engineering, Firoozabad branch, Islamic Azad University, \\ Firoozabad, Iran
}

May 5, 2020

\begin{abstract}
In this research, the application of nanoparticles for cooling in the drilling operation is investigated, experimentally. In addition, the mathematical model is derived for perdition of temperature profile in drilling zone. A solid cylinder which is equipped by heat pipe is used for evaluation of drill performance. The numerical results of the mathematical model are compared with the experimental data, finally. Studies show that nano fluid injection into the heat pipe has a significant effect on the reducing temperature profile. The results show that when the distance between the tip of the heat pipe and the tip of the drill per drill length is equal to 0.15 , also the cutting length per the drill diameter is 1 and the input heat flux is $0.33 \mathrm{w} / \mathrm{m} . \mathrm{K}$, The best ratio of the heat pipe diameter to the drill diameter will be 0.1. In this study, the different types of greases between heat pipe and inner surface of drill have been used and their influence on temperature profile has been shown.
\end{abstract}

\section{Hosted file}

baznegari shodeh-Manuscript-19-11-98.docx available at https://authorea.com/users/299692/ articles/429222-application-of-heat-pipe-and-nano-fluid-in-the-structure-of-drill-fordrilling-process-experimental-and-mathematical-evaluation

\section{Hosted file}

Figure caption.docx available at https://authorea.com/users/299692/articles/429222application-of-heat-pipe-and-nano-fluid-in-the-structure-of-drill-for-drilling-processexperimental-and-mathematical-evaluation 